\title{
USE OF THE SWAT MODEL FOR HYDRO-SEDIMENTOLOGIC SIMULATION IN A SMALL RURAL WATERSHED(1)
}

\author{
Talita Uzeika ${ }^{(2)}$, Gustavo H. Merten(3), Jean P.G. Minella ${ }^{(4)} \&$ \\ Michele Moro ${ }^{(5)}$
}

\begin{abstract}
SUMMARY
Mathematical models have great potential to support land use planning, with the goal of improving water and land quality. Before using a model, however, the model must demonstrate that it can correctly simulate the hydrological and erosive processes of a given site. The SWAT model (Soil and Water Assessment Tool) was developed in the United States to evaluate the effects of conservation agriculture on hydrological processes and water quality at the watershed scale. This model was initially proposed for use without calibration, which would eliminate the need for measured hydro-sedimentologic data. In this study, the SWAT model was evaluated in a small rural watershed $\left(1.19 \mathrm{~km}^{2}\right)$ located on the basalt slopes of the state of Rio Grande do Sul in southern Brazil, where farmers have been using cover crops associated with minimum tillage to control soil erosion. Values simulated by the model were compared with measured hydrosedimentological data. Results for surface and total runoff on a daily basis were considered unsatisfactory (Nash-Sutcliffe efficiency coefficient - NSE < 0.5). However simulation results on monthly and annual scales were significantly better. With regard to the erosion process, the simulated sediment yields for all years of the study were unsatisfactory in comparison with the observed values on a daily and monthly basis (NSE values <-6), and overestimated the annual sediment yield by more than $100 \%$.
\end{abstract}

Index terms: soil and management, water erosion, sediment yield, hydrologic modeling.

(1) Received for publication in May 3, 2011 and approved in December 1, 2011.

(2) Civil Engineer, Master in Water Resources and Environmental Sanitation by the Institute of Hydraulic Research at the Federal University of Rio Grande do Sul - UFRGS. Av. Bento Gonçalves 9500, CEP 91501-970 Porto Alegre (RS). E-mail: tali. uzeika@gmail.com

(3) Associate Professor at the Institute of Hydraulic Research, UFRGS. E-mail: merten@iph.ufrgs.br

(4) Associate Professor, Department of Soils of the Federal University of Santa Maria, UFSM. University Campus, CEP 97105-900 Santa Maria (RS). E-mail: jminella@gmail.com

(5) Ph.D. in Water Resources and Environmental Sanitation at the Institute of Hydraulic Research, UFRGS. E-mail: michelemoro@ gmail.com 


\title{
RESUMO: APLICABILIDADE DO MODELO SWAT NA SIMULAÇÃO HI- DROSSEDIMENTOLÓGICA EM UMA PEQUENA BACIA HI- DROGRÁFICA RURAL
}

\begin{abstract}
Modelos matemáticos apresentam grande potencial para serem utilizados como instrumento de apoio ao planejamento de uso da terra, com o propósito de melhorar a qualidade do solo e da água. A utilização de um modelo, no entanto, deve ser antecedida de uma etapa inicial, a fim de verificar o desempenho dele em simular corretamente os processos hidrológicos e erosivos de um dado local. O modelo SWAT (Soil and Water Acesamente Tool) foi desenvolvido nos Estados Unidos para avaliar os efeitos da agricultura conservacionista sobre os processos hidrológicos e de qualidade de água na escala de bacia. Esse modelo foi inicialmente proposto para ser utilizado sem a necessidade de calibração, o que dispensaria o uso de dados hidrossedimentológicos medidos. Nessa condição, o modelo SWAT foi avaliado em uma pequena bacia rural $\left(1,19 \mathrm{~km}^{2}\right)$ localizada nas encostas basálticas do Estado do Rio Grande do Sul, onde culturas de cobertura associadas com o cultivo mínimo vêm sendo empregadas pelos agricultores para controlar o processo erosivo. Valores simulados pelo modelo SWAT foram comparados com dados hidrossedimentológicos medidos. Como resultado da simulação, verificou-se que o escoamento superficial e o total, para a escala de tempo diária, foram considerados insatisfatórios (valores de COE $<0,5$ ). Já as mesmas simulações para as escalas mensal e anual apresentaram resultados sensivelmente melhores. Com relação ao processo erosivo, verificou-se para todos os anos que a produção de sedimentos simulada, quando comparada com os valores observados, foi insatisfatória para as simulações diárias e mensais (valores de $C O E<-6$ ) e superestimou em mais de $100 \%$ a produção de sedimentos anual.
\end{abstract}

Termos de indexação: manejo do solo, erosão hídrica, produção de sedimentos, modelo hydrológico.

\section{INTRODUCTION}

Mathematical models have been used to assist in planning improvements in soil and water conservation practices (Arnold et al., 1999; Jha et al., 2006; Borah et al., 2006). To perform these functions, however, the models must be able to simulate hydrologic processes as well as track the transference of sediments and pollutants to the drainage network.

Among the several mathematical models currently in use, the SWAT model stands apart (Arnold et al., 1998; Arnold \& Fohrer, 2005). This model has been widely used with good results, both in the U.S. and elsewhere in the world, to evaluate the effects of land use and soil management on hydrology, sediment yield (CEAP, 2010) and water quality (Borah et al., 2006; Benham et al., 2006). In Brazil, the SWAT model has great potential to be used as a support tool for planning an appropriate land use to improve water quality. Potential applications would be by watershed committees, for water resource management, water supply companies (Minoti, 2006) and for hydroelectric power generation projects (Andriolo et al., 2008).

The SWAT model (Arnold et al., 1998; Arnold \& Fohrer, 2005) was initially developed to be applied to ungauged basins (Gassman et al., 2007). This means that the SWAT model could be applied without calibration since this step implies the need for good quality hydro-sedimentological monitoring data (consistent time series). This information is quite rare in the world, except in the U.S. and some European countries.

The United States Department of Agriculture (USDA) together with American universities developed the SWAT model based on a comprehensive database (Burford \& Clark, 1973) from gauged basins in that country. Therefore, for American conditions, the simulation could be performed without the need for calibration. While the possibility of using a model without calibration may be appealing, it is unlikely that a model would be able to perform adequate hydro-sedimentolgical simulations in regions other than those for which the model was developed. The best way to assess the performance of a mathematical model at a given location is by comparing simulated results with actual monitoring data.

In Brazil, the SWAT model has been used to assess the effects of different land use and soil management scenarios on hydrology and sediment yield (Oliveira et al., 1999; Machado \& Vettorazzi, 2003; Baldissera, 2005; Moro et al., 2005; Prado 
et al., 2006; Minoti, 2006; Adriolo et al., 2008). However, studies where the simulated data are compared to the observed data, based on situations where the model was applied with and without calibration, are rarely found. This study aimed to evaluate the efficiency and limitations of the SWAT model without calibration to simulate different time scales (daily, monthly and annual), runoff and sediment yield.

\section{MATERIALS AND METHODS}

\section{Study area description}

The $1.19 \mathrm{~km}^{2}$ rural watershed used for this study is located in southern Brazil, in the municipality of Arvorezinha, in the northeastern region of the State of Rio Grande do Sul (28 $52^{\prime} 10^{\prime \prime} \mathrm{S}$ and $52^{\circ}$ $\left.10^{\prime} 30^{\prime} \mathrm{W}\right)$. Water and sediment discharge drain through the Lajeado Ferreira brook which is a tributary of the Guaporé River (Taquari-Antas basin). According to the Köppen classification, the Arvorezinha watershed is inserted in a Cfb climate region - temperate, super humid, mesothermal climate with cool summers and frequent severe frosts. The average daily temperature of the warmest month is below $22^{\circ} \mathrm{C}$, and of the coolest month is over $3{ }^{\circ} \mathrm{C}$. Annual rainfall varies from 1250 to $2000 \mathrm{~mm}$, and is well distributed throughout the year, without a defined dry or rainy season (Nimer, 1990).

Topography ranges from flat to mountainous. Basalt is the common parent soil material, from which soils such as Ultisols, Entisols and Cambisols were formed according to the relief (Embrapa, 2006). The native vegetation consists of subtropical Brazilian Atlantic Rainforest.

\section{Hydro-sedimentological monitoring}

Five rain gauges were installed in the Arvorezinha watershed. To monitor water flow at the outlet, a Parshall flume was built with a level sensor/ levellogger to continuously record the water level. The suspended sediment load discharge is determined by the product of the flow rate (Q) and the suspended sediment concentration (SSC), the latter obtained manually using an isokinetic sediment hand sampler U.S. DH-48 (Edwards \& Glysson, 1998), which determines the SSC by the evaporation method (Guy, 1969). Sediment yield (SY) is calculated by relating the sediment load discharge with the duration of each event (Minella et al., 2008). Details of monitoring, separation of surface runoff from total flow discharge (baseflow + runoff) obtained by an observed hydrograph, climatic data and observed sediment load discharge were described by Uzeika (2009). The observed data used to compare the values simulated by the SWAT model correspond to the monitoring series from 2002 to 2006.

Input soil parameters used in the model were measured in the entire watershed, considering the different land uses and soil managements (Dalbianco, 2009).

\section{Using the SWAT Model}

The SWAT model (Arnold et al., 1998; Arnold \& Fohrer, 2005) is a hydro-sedimentologic model at the watershed scale, usually applied in continuous-time simulations that can be discretized in monthly, daily and sub-daily scales. Thus, the input data to feed the model must be adjusted to the spatial and temporal dynamics of the processes occurring in the target watershed. The input data (cartographic databases - data layers and tabular data) are inserted through an appropriate interface. The required layers are: digital elevation model (DEM); soil type; land use/ management, and watershed limits. The interface developed between SWAT and ArcGis $₫$, in addition to facilitating data input in the model, automatically subdivides the watershed into sub-sections based on the DEM and the drainage network, and then lists the input data for each sub-watershed. This interface also enables the display of the model output data as maps, charts and tables.

The relief of the watershed was obtained by georeferencing and scanning of topographic maps (Brasil, 1979), scale 1:50.000, with $20 \mathrm{~m}$ intervals between the topographic contour lines. Using the Arcview ${ }^{\circledR}$ topogrid tool, contour lines were inferred (Hutchinson, 1996), generating the numerical terrain model (MNT) with altitudes ranging from 560 to $750 \mathrm{~m}$ asl. By applying the SWAT model, the Arvorezinha watershed was subdivided into three sub-basins. The criterion for the subdivision was a minimum area of 6 ha. Thus, the model automatically sets the confluences that delimit areas greater than those specified by the user.

Land use and soil management data over five years were used, but the different uses and delineation of plots invalidated the continuous simulation of five years of data. This occured because the SWAT model only allows for the entry of one land use and soil management map. Therefore, each year was simulated separately. Land use and soil management maps were obtained from annual surveys, with the aid of a GPS with an accuracy of $\pm 20 \mathrm{~m}$. All fields in the watershed were included in these surveys and use and management data for each area were collected. Then the data were entered into ArcGis ${ }^{\circledR}$ and later into SWAT. Details of all procedures employed in the use of the SWAT model related to this article were described in detail by Uzeika (2009). 
Table 1 shows the main land uses and soil management in the Arvorezinha watershed for the five years of simulated data and changes in land use and soil management.

For the simulations performed annually without calibration, data from the two years before the evaluated year was used. This strategy was used for model warming (stability) during the interactive procedures to obtain results. To validate the model, the Nash-Sutcliffe Efficiency coefficient (NSE) was used (Nash \& Sutcliffe, 1970), as this statistic has been widely used in validation of the SWAT model (Gassman et al., 2007).

\section{RESULTS AND DISCUSSION}

Between 2004 and 2008, a number of agricultural practices of soil and water conservation (cover crops combined with minimum tillage) were introduced by rural extension agents. These practices were then gradually adopted by farmers, resulting in a reduction in erosion and sediment yield (Minella et al., 2008) and improved soil quality.

\section{Suface and total runoff}

Table 2 shows the values of the NSE for daily and monthly runoff simulations and the total flow discharge for the five years of simulation. The NSE values for daily runoff were unsatisfactory for all years of simulation. The daily simulations of total flow discharge were slightly higher, but the NSE values show a low relation between the simulated and observed values. The main limitation of SWAT to represent the variables on a daily scale is related to the short, rapid rainfall events that occur in small headwater watersheds (Minella et al., 2011). These events are characterized by complex hydrographs that are highly dependent on rainfall characteristics. On a monthly scale, the errors, both over and underestimated, are compensated, resulting in a better fit with the observed values.

The NSE values may vary from - $\infty$ to 1 . A perfect fit between simulated and observed values (slope $=$ 1 and the independent term $=0$ ) was attributed to the value 1. A negative NSE value indicates that the mean values observed predict more adequately than the model used (Nash \& Sutcliffe, 1970). Moriasi et al. (2007) suggested that a NSE greater than 0.50 should be considered suitable for hydrologic simulations in terms of monthly time scales, while for the daily scale this value could be slightly lower, and necessarily higher than 0.50 when considering the annual time scale.

NSE runoff simulation values are more realistic on a monthly scale than when compared on a daily scale, with the exception of 2004, when the NSE value was extremely low (0.02). In total monthly runoff simulations, NSE values were also higher when compared to the daily values. The NSE values for simulations of total flow discharge in 2004 were significantly worse than in other years, which may be due to a smaller volume of rainfall that year (Table 2). In monthly flow discharge simulations for 2006, which was also a year with a belowaverage rainfall, this trend was also confirmed. For that same year, however, the total flow discharge simulation showed a satisfactory NSE value (0.79). The fact that the model adequately simulated total monthly flow discharge, without calibration, shows a positive aspect of SWAT. However it is also worth mentioning that or the total rainfall, the hydrograph separation line of rainfall excess (runoff) from baseflow is a complex process associated with great uncertainty. This is due to a significant interflow (lateral water flow that returns to the land

Table 1. Land use and soil management in the Arvorezinha watershed during the simulated period

\begin{tabular}{|c|c|c|c|c|c|}
\hline \multirow{2}{*}{ Land use } & \multicolumn{5}{|c|}{ Area (\%) } \\
\hline & 2002 & 2003 & 2004 & 2005 & 2006 \\
\hline Forest & 52.7 & 42.3 & 38.0 & 33.5 & 33.5 \\
\hline Pasture & 15.2 & 12.0 & 8.7 & 8.6 & 9.0 \\
\hline Tobacco conventional tillage & 24.6 & 37.4 & 28.9 & 16.9 & 18.2 \\
\hline Tobacco minimum tillage & - & - & 4.2 & 17.2 & 16.8 \\
\hline Tobacco no-tillage & - & - & 12.9 & 19.0 & 20.1 \\
\hline Beans & - & - & - & 0.1 & - \\
\hline Corn & 7.5 & 8.3 & 5.2 & 2.6 & - \\
\hline Water ${ }^{(1)}$ & - & - & 2.1 & 2.1 & 2.4 \\
\hline
\end{tabular}

(1) The water use was not computed for the years of 2002 and 2003 due to the low detail level in surveys. 
Table 2. Values of rainfall and NSE for surface runoff (daily and monthly) and total runoff (daily and monthly) obtained by the SWAT model

\begin{tabular}{cccccc}
\hline \multirow{2}{*}{ Year } & \multirow{2}{*}{ Rainfall } & \multicolumn{4}{c}{ NSE } \\
\cline { 3 - 6 } & Daily runoff & Monthly runoff & Total daily flow ${ }^{(1)}$ & Total monthly flow $^{(1)}$ \\
\hline & $\mathrm{mm}$ & -0.27 & 0.26 & 0.44 & 0.67 \\
2002 & 2,219 & -0.22 & 0.71 & 0.09 & 0.84 \\
2003 & 1,835 & -0.07 & 0.02 & -1.94 & 0.45 \\
2004 & 1,324 & 0.16 & 0.90 & -0.38 & 0.72 \\
2005 & 1,935 & -0.71 & 0.35 & 0.79 & 0.81 \\
\hline
\end{tabular}

(1) Total flow represents baseflow plus runoff or overlandflow in the fluvial channel. Mean annual long-term rainfall $=1,791$.

or stream without first reaching groundwater) in the stormflow. In the Arvorezinha watershed the interflow is caused by the presence of shallow soils with textural gradient associated with planting ridges in tobacco fields.

Figure 1 illustrates the monthly total flow discharge simulations. For this graph, the consistency between rainfall and total flow discharge at the monthly scale is good, indicating the adequate water transfer from the watershed to the fluvial channel. Another aspect observed is the model's tendency to underestimate the total flow discharge in wetter years (2002) and to overestimate it in drier years (2004).

Overall, for both runoff and total flow discharge, studies reported that SWAT presents low NSE values for daily simulations, regardless of calibration (Gassman et al., 2007). Factors such as inadequate representation of the spatial variability of rainfall data (Cao et al., 2006), lack of calibration (Bosch et al., 2004), errors in water discharge measurement (Harmel et al., 2006) and a short observation period have been cited to justify this condition. Gassmann et al. (2007) analyzed the performance of the SWAT model using data from 115 papers published in different parts of the world. In this article, for the work carried out in small watersheds (under $30 \mathrm{~km}^{2}$ ), NSE values for total flow discharge and runoff simulations on a daily scale were also low (below 0.5). However for hydrological simulations at the monthly scale, NSE values were appropriate, independent of whether the model had been calibrated or not. This shows that the results of the hydrological simulations carried out in this study are consistent with other evaluations of SWAT. Another important aspect observed in the work of Gassmann et al. (2007) refers to the relationship between the watershed area and the NSE value. Higher NSE values were observed in larger watersheds, which can be justified by the difficulty of simulating small watersheds. In general, small watersheds have low concentration time and low capacity to minimize the peak runnoff, similar to what was observed in the Arvorezinha watershed.

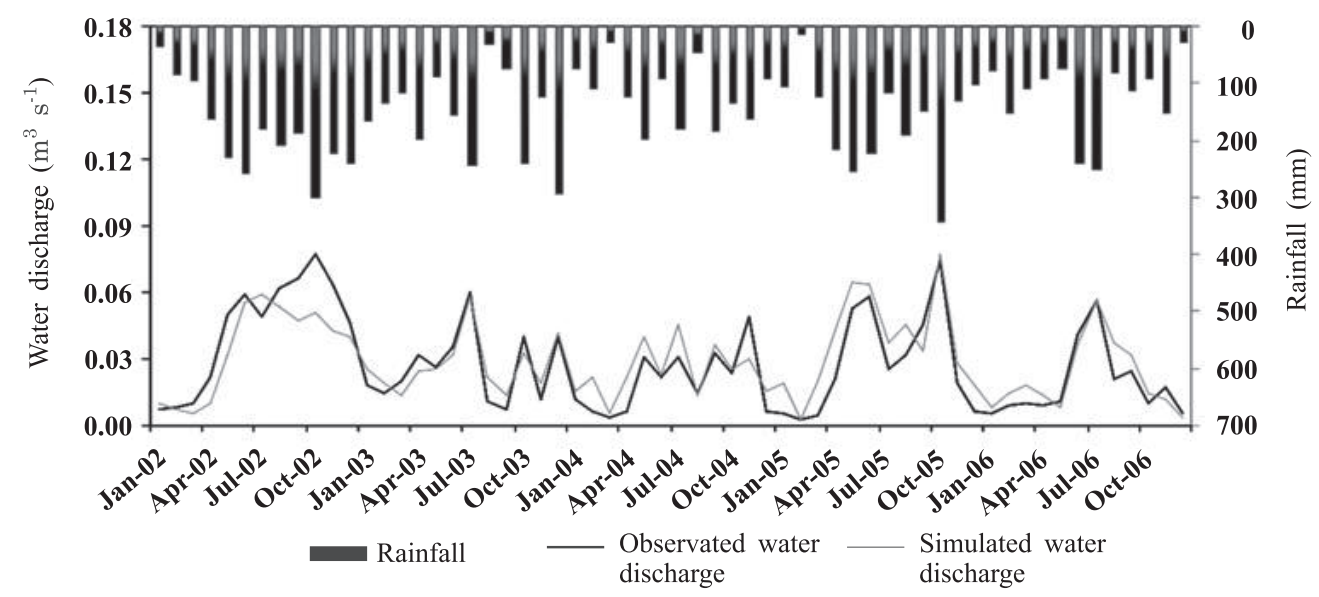

Figure 1. Total monthly flow discharge (observed and simulated) vs rainfall from 2002 to 2006. 


\section{Sediment yield Simulation}

The SWAT model estimates the sediment input using the Modified Universal Equation for Soil LossMUSLE (Williams \& Berndt, 1977). This equation uses the same parameters as the Universal Soil Loss Equation - USLE (Wischmeier \& Smith, 1978), except for the erosivity factor ( $\mathrm{R}$ factor) which in MUSLE is replaced by the product of the volume of the runoff $\left(\mathrm{m}^{3}\right)$ and the runoff peak $\left(\mathrm{m}^{3} \mathrm{~s}^{-1}\right)$ of stormflow. When the runoff, along with the sediment load (mass of sediment mobilized by erosion), reaches the fluvial channel, the propagation phase of these sediments in the drainage network begins. The sediment yield or load refers to the total amount of sediment that exits a drainage basin over a given period of time.

Table 3 shows the NSE values for daily and monthly sediment yield simulations. Unlike observed for both surface and total runoff, NSE values indicate that the model was not able to reproduce the estimated daily and monthly sediment yield adequately for each evaluated year. In general, the SWAT model significantly overestimated sediment yield for both time scales.

Table 4 shows the comparison of annual sediment yield simulations with the observed values. Sediment yield values were overestimated for all years, especially for 2006. Considering the average simulated and observed sediment yield values, the results indicate a 5 -fold overestimation.

Gassmann et al. (2007) report a series of data on sediment yield simulated by SWAT in various watersheds worldwide. For small watersheds, with the exception of one study (Muleta \& Nicklow, 2005), observed NSE values have shown that the model could adequately simulate sediment yield on daily, monthly and yearly time scales. In addition, in two citations where SWAT was not calibrated (Machado \& Vettorazzi, 2003; Tripathi et al., 2003), NSE values were also adequate (NSE > 0.5).

Viero et al. (2009), working in the Arvorezinha watershed and using the WaTEM/SEDEM model
(Van Oost et al., 2000) found that this model overestimated the sediment yield between 16 and 150 times, when compared with observed values. The authors attributed the results to two limiting factors: the low quality of the DEM, which did not allow for an adequate representation of the microtopography of the watershed surface, and also due to the fact that the WaTEM/SEDEM model does not simulate the erosion process that occurs in the fluvial channel.

\section{Factors related to the overestimation of sedi- ment yield}

As previously mentioned, the results for sediment yield obtained in this study (Tables 3 and 4) were different from those results reported by Gassmann et al. (2007). Hydrological results simulated by SWAT on the daily scale showed limitations when used for small watersheds without calibration. The response to rainfall in the Arvorezinha watershed is characterized by a rapidly evolving hydrological process, with erosion within few hours between the beginning of runoff and the falling limb of the hydrograph. Thus, the proper representation of the hydrological process of a small watershed would be linked to the model ability to simulate this condition. The time of concentration, the slope of the falling limb of the hydrograph and runoff volume are key features to be incorporated into the hydrologic simulation of small watersheds, to ensure an adequate simulation of sediment yield. As mentioned, the results of daily runoff simulations were not satisfactory, which indicates mainly that the estimation of the runoff by the model was not correct for the daily scale, since the rainfall events occur on a sub-daily time-scale.

Another important aspect to be considered is the simplification of the LS factor in SWAT calculations. The LS factor is calculated automatically from the DEM for each hydrological response unit (HRU) as follows: $\mathrm{L}$ represents the distance between the extreme points of HRU, while $\mathrm{S}$ is based on the

Table 3. NSE results for daily sediment yield from 2002 to 2006

\begin{tabular}{cccc}
\hline \multirow{2}{*}{ Year } & Rainfall & \multicolumn{2}{c}{ NSE } \\
\cline { 3 - 4 } & & Daily sediment yield & Monthly sediment yield \\
\hline & $\mathrm{mm}$ & & -77.38 \\
2002 & 2,219 & -12.20 & -27.89 \\
2003 & 1,835 & -17.36 & -7.06 \\
2005 & 1,324 & -7.77 & -6.53 \\
2006 & 1,935 & -9.82 & -241.63 \\
\hline
\end{tabular}


Table 4. Simulation results of specific SY obtained by the SWAT model simulation and compared with the observed values (2002 to 2006)

\begin{tabular}{|c|c|c|c|c|}
\hline \multirow{2}{*}{ Year } & \multirow{2}{*}{ Rainfall } & \multicolumn{2}{|c|}{ Sediment yield } & \multirow{2}{*}{ Difference } \\
\hline & & Observed & Simulated & \\
\hline & $\mathrm{mm}$ & $\longrightarrow$ & $\mathrm{r}^{-1}$ & $\%$ \\
\hline 2002 & 2,219 & 219 & 983 & 349 \\
\hline 2003 & 1,835 & 231 & 907 & 293 \\
\hline 2004 & 1,324 & 72 & 188 & 161 \\
\hline 2005 & 1,935 & 142 & 406 & 186 \\
\hline 2006 & 1,409 & 69 & 1,021 & 1,380 \\
\hline Average & $1,791^{*}$ & 147 & 701 & 474 \\
\hline
\end{tabular}

*: Mean annual long-term rainfall.

difference between the heights of these points. The use of extremes for each HRU certainly results in an increase of the LS factor value, hence overestimating sediment yield. This simplified way of calculating the LS factor does not consider sediment deposition between the extreme points and may represent a major source of errors in the results observed in this work.

Minella et al. (2010), comparing different procedures for calculating the LS factor in the Arvorezinha watershed, found important differences between simplified methods and methods that take into account the spatial representation of a watershed area. The SWAT model would be more robust in its estimation of sediment yield if the LS factor could be replaced by methods that consider the spatial representation of the area of a watershed, according to the procedures proposed by Moore \& Burch (1986) or Desmet \& Govers (1996). Benatto et al. (2006) used USLE and a sediment delivery ratio (SDR) based on the watershed area to calculate SY for the Arvorezinha watershed, where the LS factor was estimated using the computational procedure proposed by Moore \& Burch (1986). Results obtained were consistent with the observed sediment yield in the watershed, which indicates that the USLE base for MUSLE used in SWAT has the potential to simulate the erosion processes, as long as the complexity of the LS factor is adequately represented and adjusted as a parameter of sediment emission, similar to the SDR.

An important consideration is also with regard to the process of transport of river sediment to the fluvial channel. A positive aspect of the SWAT model is that it considers that the processes in the drainage basin are linked with those that occur in the fluvial channel. On the other hand, the complexity of the processes occurring in the fluvial channel is simplified by the SWAT model (Gassmann et al., 2007). For example, when simulating sediment yield in an HRU, which in turn is contained in a sub-basin, the entire sediment load mobilized in the URH is transferred to the fluvial channel. This rarely occurs in reality, because a significant proportion of the sediment is deposited between the drainage basin and the fluvial channel. In the case of the Arvorezinha watershed, Moro (2011) calibrated the distributed erosion model LISEM (Limburg Soil Erosion Model), and found significant sediment deposition of eroded material at the base of the slopes. Using the Cs-137 technique in the same watershed, Minella found that from the total sediment load that is mobilized in the watershed, only $40 \%$ is transferred to the fluvial channel. Thus, a possible source of error in estimating the observed sediment yield for the Arvorezinha watershed is related to the inability of the model to simulate the process occurring between the area of sediment deposition and the fluvial channel. In general, the DEM available for small watersheds are still quite limited in representing the relief adequately and thereby erosion modeling, especially of depositions.

Another important factor to be considered is the need for model calibration. In the U.S., where the model was developed from a large and representative set of experimental watersheds, the developers of the model suggest that it may be used without calibration. However, results obtained in this work indicate that for different climatic and physiographic conditions without calibration, the simulation may produce unsatisfactory results.

This is especially important for small watersheds where the processes of generating surface and erosive runoff are non-linear. At daily intervals, the SWAT model is unable to represent the complexity and magnitude of the hydrographs and sedimentographs 
during an event. However on monthly and annual scales, daily values are added up, and the errors compensate each other, generating a better fit with the observed values.

Therefore, calibration minimizes the errors from the simplified simulation of the processes being modeled. This reinforces the need to expand the Brazilian hydro-sedimentological research network at the watershed scale so that mathematical modeling may be used as a more accurate means of planning an appropriate use of natural resources.

\section{CONCLUSIONS}

1. The SWAT model, when used without calibration, was able to adequately reproduce runoff and total flow discharge on monthly and annual time scales but not on daily scales.

2. Sediment yield simulations were overestimated for all time scales (daily, monthly and annual) and throughout the entire simulated period.

3. Factors such as the use of SWAT without calibration, and the model's limitations in representing the hydrological and sedimentological processes for small watersheds could be responsible for these results.

\section{LITERATURE CITED}

ANDRIOLO, M.V.; SANTOS, I.; GIBERTONI, R.C. \& CAMARGO, A.S.G. Calibração do modelo SWAT para a produção e transporte de sedimentos. In: SIMPÓSIO SOBRE PEQUENAS E MÉDIAS CENTRAIS HIDRELÉTRICAS, 6., Belo Horizonte. Anais... SPMCH, 2008. p.1-17.

ARNOLD, J.G. \& FOHRER, N. SWAT2000: Current capabilities and research opportunities in applied watershed modeling. Hydrol. Process., 19:563-572, 2005.

ARNOLD, J.G.; SRINIVASAN, R.; MUTTIAH, P.M. \& ALLEN, P.M. Continental-scale simulation of the hydrologic balance. J. Am. Res. Assoc., 35:1037-1052, 1999.

ARNOLD, J.G.; SRINIVASAN, R.; MUTTIAH, R.S. \& WILLIAMS, J.R. Large area hydrologic modeling and assessment. Part I: Model development. J. Am. Water Res. Assoc., 34:73-89, 1998.

BALDISSERA, G.C. Aplicabilidade do modelo de simulação hidrológica SWAT (SoilandWaterAssessment Tool), para a bacia hidrográfica do Rio Cuiabá. Cuiabá, Universidade Federal do Mato Grosso, 2005. 144p. (Tese de Mestrado)

BENATTO, L.; MINELLA, J.P.G. \& MERTEN, G.H. Estimativa de perda de solo através da Equação Universal de Perdas de Solo considerando diferentes cenários de manejo de solo. In: ENCONTRO NACIONAL DE ENGENHARIA DE SEDIMENTOS. Sedimentos: O desafio da multidisciplinaridade, 7., Porto Alegre, 2006. Anais... Porto Alegre, ABRH. 2006. CD ROM.
BENHAM, B.L.; BAFFAUT, C.; ZECKOSKI, R.W.; MANKIN, K.R.; PACHEPSKY, Y.A.; SADEGHI, A.M.; BRANNAN, K.M.; SOUPIR, M.L. \& HABERSACK, M.J. Modeling bacteria fate and transport in watershed models to support TMDLs. Trans. ASABE, 49:987-1007, 2006.

BORAH, D.K.; YAGOW, G.; SALEH, A.; BARNES, P.L.; ROSENTHAL, W.; KRUG, E.C. \& HAUCK, L.M. Sedimentation and nutrient modeling for TMDL development and implementation. Trans. ASABE, 49:967986, 2006.

BOSCH, D.D.; SHERIDAN, J.M.; BATTEN, H.L. \& ARNOLD, J.G. Evaluation of the SWAT model on a coastal plain agricultural watershed. Trans. ASAE, 47:1493-1506, 2004.

BRASIL. Ministério do Exército. Departamento de Engenharia e Comunicações. Diretoria do Serviço Geográfico do Exército - DSG. Folha SH. 22-V-BIV-4 de Arvorezinha. Porto Alegre, 1979. Escala 1:50.000.

BURFORD, J.B. \& CLARK, J.M. Hydrologic data for experimental agricultural watersheds in the United States 1967. Washington, USDA, 1973. 634p. (Publication, 1262)

CAO, W.; BOWDEN, W.B.; DAVIE, T. \& FENEMOR, A. Multivariable and multi-site calibration and validation of SWAT in a large mountainous catchment with high spatial variability. Hydrol. Proc., 20:1057-1073, 2006.

DALBIANCO, L. Variabilidade espacial e estimativa da condutividade hidráulica e caracterização físico-hídrica de uma microbacia hidrográfica rural. Santa Maria, Universidade Federal de Santa Maria, 2009. 116p.

DESMET, P.J. \& GOVERS, G. A GIS procedure for automatically calculating the USLE LS factor on topographically complex landscape units. J. Soil Water Conserv., 51:427-433, 1996.

EDWARDS, T.K. \& GLYSSON, G.D. Field methods for measurement of fluvial sediment. US GeologicalSurvey Open-File Report 86-531. 1998. 118p.

EMPRESA BRASILEIRA DE PESQUISA AGROPECUÁRIA EMBRAPA. Centro Nacional de Pesquisa de Solos. Sistema brasileiro de classificação de solos.. 2.ed. Rio de Janeiro, Embrapa Solos, 2006. 306p.

GASSMAN, P.W.; REYES, M.; GREEN, C.H. \& ARNOLD, J.G. The soil and water assessment tool: Historical development, applications, and future directions. Trans. ASABE, 50:12111250, 2007.

GUY, H.P. Laboratory theory and methods for sediment analysis: U.S. Geological Survey Techniques of Water-Resources Investigations. Washington, DC, C1 US Government Printing Office, 1969. v.5. 58p.

HARMEL, R.D.; RICHARDSON, C.W. \& KING, K.W. Hydrologic response of a small watershed model to generated precipitation. Trans. ASAE, 43:1483-1488, 2006.

HUTCHINSON, M.F. A Locally Adaptive Approach to the Interpolation of Digital Elevation Models. In: In:INTERNATIONAL CONFERENCE / WORKSHOP ON INTEGRATING GIS AND ENVIRONMENTAL MODELING, 3., Santa Fe, 1996. Proceedings... Santa Fe, 1996. <Abailable at: http://www.ncgia.ucsb.edu/conf> 
JHA, M.; ARNOLD, J.G.; GASSMAN, P.W.; GIORGI, F. \& GU, R. Climate change sensitivity assessment on upper Mississippi river basin steam flows using SWAT. J. Am. Water Res. Assoc., 42:997-1015, 2006.

MACHADO, R.E. \& VETTORAZZI, C.A. Simulação da produção de sedimentos para a microbacia hidrográfica de Ribeirão dos Marins (SP). R. Bras. Ci. Solo, 27:735-741, 2003.

MINELLA, J.P.G.; MERTEN, G.H. \& MAGNAGO, P.F. Análise qualitativa e quantitativa da histerese entre vazão e concentração de sedimentos durante eventos hidrológicos. R. Bras. Eng. Agric. Amb., 15:1306-1313, 2011.

MINELLA, J.P.G.; WALLING, D. \& MERTEN, G. Combining sediment source tracing techniques with traditional monitoring to assess the impact of improved land management on catchment sediment yields. J. Hydrol., 348:546-563, 2008.

MINELLA, J.P.G.; MERTEN, G.H. \& RUHOFF, A.L. Utilização de métodos de representação espacial para cálculo do fator topográfico da Equação Universal de Perdas de Solo. R. Bras. Ci, Solo, 34:1445-1462, 2010.

MINOTI, R.T. Abordagens qualitativa e quantitativa de microbacias hidrográficas e áreas alagáveis de um compartimento do Médio Mogi-Superior-SP. São Carlos, Universidade de São Paulo, 2006. 231p. (Tese de Doutorado)

MOORE, I.D. \& BURCH, G.J. Sediment transport capacity of sheet and rill flow: Application of unit stream power theory. Water Res. Res., v.22, n.8. p.1350-1360, 1986.

MORIASI, D.N.; ARNOLD, J.G.; van LIEW, M.W.; BINGNER, R.L.; HARMEL, R.D. \& VEITH, T.L. Model evaluation guidelines for systematic quantification of accuracy in watershed simulations. Trans. ASABE, 50:885-900, 2007.

MORO, M. Avaliação do modelo LISEM na simulação dos processos hidrossedimentológicos de uma pequena bacia rural localizada nas encostas basálticas do Rio Grande do Sul. Porto Alegre, Universidade Federal do Rio Grande do Sul, 2011. 123p. (Tese de Doutorado)

MORO, M.; CRUCIANI, D.E.; VETTORAZZI, C.A.; MACHADO, R.E. Aplicação do modelo SWAT para simulação da produção de sedimentos em uma microbacia hidrográfica em cenários alternativos de uso do solo. In: VII Encontro Nacional de Engenharia de Sedimentos, 2006, Porto Alegre. VII Encontro Nacional de Engenharia de Sedimentos. Porto Alegre : ABRH, 2006.

MULETA, M.K. \& NICKLOW, J.W. Sensitivity and uncertainty analysis coupled with automatic calibration for a disturbed watershed model. J. Hydrol., 306:127-145, 2005.
NASH, J.E. \& SUTCLIFFE, J.V. River flow forecasting through conceptual models. Part 1: A discussion of principles. J. Hydrol., 10:282-290, 1970.

NIMER, E. Clima. In: FUNDAÇÃO INSTITUTO BRASILEIRO DE GEOGRAFIA E ESTATÍSTICA. GEOGRAFIA: Região sul. Rio de Janeiro, 1990.

OLIVEIRA, M.Q.C.; DOMINGUEZ, J.M.L.; MEDEIROS, Y.D.P. Impacto de mudanças no uso do solo nas características hidrossedimentológicas da Bacia Hidrográfica do Rio Joanes e sua repercussão na zona costeira. Anais: VII Congresso da ABEQUA. Porto Seguro. viiabequa_ico006.pdf. (1999).

PRADO, T. B. G.; MORAES, J. F. L.; ADAMI, S. F. Evolução do uso das terras e produção de sedimentos na bacia hidrográfica do Rio Jundiaí-Mirim. Acta Scientiarum (UEM), v. 1, p. 1-10, 2006.

TRIPATHI, M.P.; PANDA, R.K. \& RAGHUWANSHI, N.S. Identification and prioritization of critical sub-watersheds for soil conservation management using the SWAT Model. Biosyst. Eng., 85:365-379, 2003.

CONSERVATION EFFECTS ASSESSMENT PROJECT - CEAP. Assessment of the effects of conservation practices on cultivated cropland in the Upper Mississippi river basin. Wshington, USDA, 2010. 146p. (Draft June, 2010)

UZEIKA, T. Aplicabilidade do modelo SWAT (Soil and Water Assessment Tool) na simulação da produção de sedimentos em uma pequena bacia hidrográfica rural. Porto Alegre, Universidade Federal do Rio Grande do Sul, 2009. 129p. (Tese de Mestrado)

VAN OOST, K.; GOVERS, G. \& DESMET, K.G. Evaluating the effects on changes in landscape structure on soil erosion by water and tillage. Landscape Ecol., 15:577-589, 2000.

VIERO, A.C.; MERTEN, G.H. \& MINELLA, J.P.G. Estimativa da produção de sedimentos através do modelo WaTem/ SEDEM In: IDE, C.N.; VAL, L.A.A. \& RIBEIRO, M.L. Produção de sedimentos e seus impactos ambientais, sociais e econômicos. Campo Grande, Oeste, 2009. p.95-112.

WILLIAMS, J.R. \& BERNDT, H.D. Sediment yield prediction based on watershed hydrology. Trans. ASAE, 20:1100$11004,1977$.

WISCHMEIER, W.H. \& SMITH, D.D. Predicting rainfall erosion losses: A guide to conservation planning. Washington, USDA, 1978. 58p. (Agricultural Handbook, 537) 
